\title{
Mathematics teacher candidates' skills of using multiple representations for division of fractions
}

\author{
Abdullah Çağrı Biber \\ Department of Mathematics Education Kastamonu University, Kastamonu, Turkey.
}

Received 23 ${ }^{\text {rd }}$ December 2013; Accepted $17^{\text {th }}$ April 2014

\begin{abstract}
The aim of this study is to reveal teacher candidates' preference regarding uses of verbal, symbolic, number line, and/or model representations of fraction divisions, and to investigate their skill of transferring from one representation type to the others. Case study was used as the research method in this study. The case that is examined within the scope of the study involves the performances of students in transiting between different representations of the fraction division. The study group consisted a total of 71 mathematics teacher candidates who were students in a university in Turkey. Among the results of the study were that the comparison of the performances of the pre-service teachers in transitions between representations reveals that the pre-service teachers were quite successful in expressing a fraction whose verbal or numeric (symbolic) expression was provided through other types of representation, but they were very unsuccessful in representing the fractions that were provided via models or on number lines through other types of representation.
\end{abstract}

Key words: Multiple representations, division of fractions, mathematics teacher candidates.

\section{INTRODUCTION}

The representations that one uses when solving mathematical problems provide us with a gateway to understanding his/her thinking (NCTM, 2000). Utilizing multiple representations during problem solving provides opportunities for the students to engage with the problem from the different aspects and to investigate deeply (Driscoll, 1999; McGowan and Tall, 2001). This is, in turn, beneficiary for robust understanding of the concepts. One theory of learning in mathematics is the multiple representations can be utilized to help students develop deeper, more flexible understanding of the concepts and processes (Even, 1998; Hiebert and Carpenter, 1992; Keller and Hirsch 1998; Piez and Voxman, 1997).

NCTM (2000) put a great emphasis on representations so that it was included in the process standards along with problem solving, reasoning and proof, communication and connection. According to NCTM, "When students gain access to mathematical representations and the ideas they express and when they can create representations to capture mathematical concepts or

E-mail: a c biber@kasta monu.edu.tr Tel: 0366-212-2314

Author agree that this artic le remain permanently open access under the terms of the Creative Commons Attribution License 4.0 Intemational License 
relationships, they acquire a set of tools that significantly expand their capacity to model and interpret physical, social and mathematical phenomena." (p.4).

The concept of representation is among the psychological terms used in the field of mathematics education to explain important phenomenon about children's thinking. Speiser and Walter (2000), who, in agreement with Davis (1984), base their assertion on the previous work of Minsky (1975) and others, when they claim that mathematical knowledge is cognitively represented symbolically, often in the form of representations that are referred to as frames. When students think about a mathematical situation, they must first build a representation, which is usually done in the form of a mental representation.

Literature shows that teaching requires improving students' skill of transiting between different representations to support conceptual learning (NCTM, 2000; Kendal, 2002; Goerdt, 2007). Being stated as the language of mathematics, representing, in general, is a modeling process of abstract concepts and symbols in a concrete way inside the real world (Kaput, 1998). By means of representations, students can learn mathematics from different aspects (Choike, 2000). Multiple representations also prepare students for advanced mathematics (Schultz and Waters, 2000). Moreover, they also provide students with different problem solving strategies and support conceptual learning (Keller and Hirsch, 1998).

Learning environments that utilize multiple representations contribute students' conceptual understandings of mathematical identities (Dufour-Janvier et al., 1987; Porzio, 1999). Among mathematical concepts, fractions are the ones that allow teachers to use multiple representations. Starting from the elementary schools, students confront with fractions that interact with natural numbers, integers and rational numbers. The difficulties that many students have experienced in the concepts of fractions and fraction operations have been well documented (Aksu, 1997; Başgün and Ersoy, 2000; Davis et al., 1991; Davis et al., 1993; Gürbüz and Birgin, 2008; İpek et al., 2005; Kamii and Clark, 1995; Mack, 1995; Pesen, 2008, Richards and Cobb, 1983; Steffe et al., 1988; Yang et al., 2008; Tzur, 1999).

Research indicates that division is the most complex one among all fraction operations. In a study conducted with teachers and students, Ma (1999) indicated that only $43 \%$ of the United States teachers were able to perform the computation successfully and only one out of twentythree teachers was able to give a correct representation for a problem involving division of fractions. In their study, Watson et al. (1993) examined how four fraction problems were solved by children from kindergarten to grade ten to analyze the work of children's use of images, reality and experience. They found a developmental progression in the iconic reasoning, the ability to reason involving images and drawings, was developed in building ideas about fractions. Lamon (2001) attributes some of the difficulties students have with fractions to their limited ability to extend the meaning of a fraction to various interpretations. She states that a fraction, such as $3 / 4$, can be interpreted as 1) a part/whole comparison 2) an operator 3) a ratio or rate 4) a quotient or 5) a mea-sure. She suggests that students should be involved in a variety of activities that will enable them to experience the meaning of fraction in a wide range of ways by means of multiple representations.

In a study conducted with the fifth grade students, Şiap and Duru (2004) indicated that students had difficulty in ordering, operating and transferring different representations of fraction. Orhun (2007) also found that fourth graders had issues with classifying, ordering, adding, multiplying and representing fractions. The study also indicated that students could not interpret the fractions that were given in visually (through modeling).

In order to balance conceptual knowledge and algorithmic knowledge, it is important for both students and teachers to transfer among the different representations of the fractions and to operate on these representations (Baki, 2006). Some studies indicated teachers' weaknesses on integrating multiple representations inside their teaching environments (Stein et al., 1990; Even, 1998; Hitt, 1998; Çelik and Baki, 2007). When taken into account that uses of multiple representations are included and emphasized in the mathematics teaching program in Turkey (MEB, 2009; MEB, 2013), teachers (of now and in future) are to know and able to use these representations. Within this regard, literature provides a lack of studies that investigates mathematics teachers' and teacher candidates' uses of multiple representations, especially in fractions. Based on the explanations and literature given above, the aim of this study was (1) to reveal teacher candidates' preference regarding uses of verbal, symbolic, number line, and/or model representations of fraction divisions and (2) to investigate their skill of transferring from one representation type to the others.

\section{METHODOLOGY OF RESEARCH}

Case study was used as the research method in this study. The case that is examined within the scope of the study involves the performances of students in transiting between different representations of the fraction division.

\section{Study group}

The study group consisted of a total of 71 mathematics teacher candidates who were students in the department of elementary 
Table 1. Distribution of question peers.

\begin{tabular}{lcc}
\hline \multirow{2}{*}{ Question peers } & \multicolumn{2}{c}{ Transition } \\
\cline { 2 - 3 } WN/WN, WN/F, F/WN, F/F & Symbol & Torbal \\
& & Model \\
& & Number Line \\
WN/WN, WN/F, F/WN, F/F & Verbal & Symbol \\
& & Model \\
& & Number Line \\
WN/WN, WN/F, F/WN, F/F & Model & Symbol \\
& & Verbal \\
& & Number Line \\
WN/WN, WN/F, F/WN, F/F & Number Line & Symbol \\
& & Model \\
\hline
\end{tabular}

WN. Whole number question, F: fraction question

mathematics education at a university in Turkey, and nobody in this group had teaching experience previously. A criterion-based purposive sampling strategy was applied in forming of the study group. The percentage of the female participants was more than double of the one of the males (70 versus $30 \%$, respectively). The criteria for selection were for all students to be in the fourth-grade and to have successfully completed the courses relating mathematics education, such as Mathematics Teaching Methods I and II.

\section{Data collection tool}

In line with the aims, this study used a multiple representations of fraction division test (MRFDT) in the concept of fraction division. MRFDT consisted of 64 questions (16 sets each with four questions), which require from teacher candidates to represent the given form of the question in other forms. In addition, data concerning which methods pre-service teachers preferred or did not prefer in demonstrating division in fractions through different representations were collected by a separate question.

For each representation type (symbolic, verbal, model, number line), students were to addressed four question requiring dividing (1) two whole numbers, (2) a whole number by another fraction, (3) a fraction by a whole number, and (4) a fraction by another fraction. MRFDT prepared by the researchers, checked and approved by an external expert who studies in the field of mathematics education, in terms of its understandability and practicability. A pilot application of the achievement test conducted with 32 students, and its understandability was found sufficient. All of the questions are open-ended, and their features are given in Table 1.

The data were collected with an exam-quality application in a single-session process of 180 minutes, and teacher candidates tried to answer the whole question set. One set of questions, which were directed towards students on the subject of rotational motion, are given in Table 2. These questions required from teacher candidates to represent symbolic form of fraction division by using area models. The operations included dividing two whole numbers (Q1), a whole number by another fraction (Q2), a fraction by a whole number (Q3), and a fraction by another fraction (Q4).

As is seen in Figure 1, since Question $3 \mathrm{C}$ required students to use their conceptual information regarding the given condition, it was considered a conceptual question. Since Question 3A required students to make algorithmic calculations and reach a numerical value, it was accepted as an algorithmic question. Since Question $3 G$ required students to express the given values on a graphic and draw the graphic, it was assessed as a graphical question.

\section{Data analysis}

The data that were obtained were initially examined in terms of the success and (correct answers) and failure (wrong and no answers) states of students. During this process, the whole analysis was conducted by the researcher in company with an external expert, who holds a doctoral degree in the field of mathematics education. The most occurred mistakes during the transitions were also provided.

\section{Findings of research}

The analysis of the answers to the question "Which methodology do you prefer to use while showing the dividing in fractions with different representations (verbal, symbol, number line and by using model) and which methodology do not you think to use?" were given in Table 3. The mostly preferred type is symbolic show (by half of the candidate teachers) for the dividing in fractions. Verbal expression and number line showing methods are individually representing $18 \%$ of the candidates. Model showing in dividing fractions represent $14 \%$ of the candidates and has the lowest percentage distribution in this category.

The least preferred methodology in dividing fractions showing is the showing on number line (by most of the candidates). The model showing method is stated by $27 \%$ of the candidates. The symbolic and statement showings have the least percentage among the showings which are preferred by the candidates representing the $27 \%$ of the candidates, as supporting the data in most preferred methodologies.

Table 4 shows the success of pre-service teachers in expressing division in fractions, which was provided verbally, through other types of representation. The examination of general averages demonstrated that although the pre-service teachers were quite successful in transition from verbal expression to symbolic representation (98\%), more than half of the pre-service teachers were unsuccessful in representations via number lines and models (that is, gave wrong answers or no answers). In addition, the preservice teachers had a difficulty in dividing a fractional number by a natural number. The pre-service teachers were found to be quite successful in division of a natural number by a natural number (example, 1:5) during transition from textual representation to other types of representation, but to have lower rates of success in operations involving the division of natural numbers by fractions [example, $1:(2 / 5)]$ or the division of fractions by fractions $[(1 / 5)$ : $(3 / 10)]$.

Table 5 includes findings about the transition of the pre-service teachers from symbolic representation including numbers to other types of representation in division in fractions. As it is seen in the 
Table 1. Sample questions, which were directed towards students on the same subject.

\begin{tabular}{|c|c|c|}
\hline & Transition from & Division requiring \\
\hline Q1: Use model to illustrate $1 \div 2$. & & WN/WN \\
\hline Q2: Use model to illustrate $4 \div \frac{1}{2}$. & & WN/F \\
\hline Q3: Use model to illustrate $\frac{2}{3} \div 3$. & Symbol to Model & F/WN \\
\hline Q4: Use model to illustrate $\frac{3}{5} \div \frac{1}{5}$ & & $F / F$ \\
\hline
\end{tabular}

Table 2. Percentage distribution of teacher candidates' preferences of fraction representations.

\begin{tabular}{lcccc}
\hline & Verbal & Number line & Symbol & Model \\
\hline Most preferred & 18 & 18 & 50 & 14 \\
Least Preferred & 9 & 55 & 9 & 27 \\
\hline
\end{tabular}

table 5, although the pre-service teachers were quite successful in expressing numerically provided division in fractions through other types of representation and in transition to textual representation (verbal expression) of fractions (88\%), they were quite unsuccessful in transition to representation via models (\%32) and numbers (\%43). In demonstrating fractions by other representations, the preservice teachers were more unsuccessful in cases where a natural number was divided by a natural number, a fraction was divided by a natural number, and a fraction was divided by a fraction. These two cases indicate that the pre-service teachers have difficulty in representing division in fractions via models and number lines.

Table 6 presents findings about the performance displayed by the pre-service teachers in transition from representation via number lines to other types of representation. As it is seen in the table 6 , although more than half of the pre-service teachers succeeded in transition from representation via number lines to symbolic representation and textual representation, they had lower success in representation via models. The number of the successful pre-service teachers decreased more in the representation of division of a natural number by a fraction. Even though the preservice teachers showed an important success in transition from representing the division of a natural number by another natural number through a number line to representing such operation through other types of representation, they were unsuccessful in other question types (number:fraction and fraction:fraction in particular). Moreover, the overall performance of the pre-service teachers in transition from representation via number lines to other types of representation was found to be lower than their performance in transition from textual representation and symbolic (numerical) representation to other types of representation.

Table 7, provides findings about the performance of the preservice teachers in transition from representation via models to other types of representation. According to the table 7, the preservice teachers had difficulty especially in representation via number lines in transition from representation via models to other types of representation. While $87 \%$ of the pre-service teachers succeeded in transition from representation of division of a natural number by a natural number via models to other types of representation, this ratio fell to $63 \%$ in division of a fractional number by a natural number, to $33 \%$ in division of a natural number by a fractional number, and to $13 \%$ in division of a fractional number by a fractional number. The fact that more than half of the pre-service teachers $(51 \%)$ did not give any answer to transition from representation via models to other types of representation in questions including the division of fractional numbers by fractional numbers indicates the problems encountered by the pre-service teachers in this matter. Furthermore, the overall performance of the pre-service teachers on this subject is similar to their performance in transition from representation via number lines to other types of representation. However, the performance of the pre-service teachers in both cases is lower than their performance in transition from textual representation and symbolic (numerical) representation to other types of representation.

Table 8, indicates the difficulties which the pre-service teachers encountered most frequently in transition from one type of representation to another. Almost half of the pre-service teachers $(n=24)$ calculated the result of fractional operation in the first place, and then fell into the error of marking such calculated value on the number line. In addition, 16 pre-service teachers showed only such final value calculated by them on the number line. Another frequently encountered representation error involved using a model instead of each number value in the fractional expression and giving the separately calculated final value via a model.

\section{RESULTS AND IMPLICATIONS}

This study investigated the preferences of pre-service teachers for using multiple representations such as verbal representation, symbolic representation, number line representation and model representation in division in fractions and their competences for using such representations and transiting between such representations. Based on the findings of the study, the results and implications of the study are provided here.

The pre-service teachers were quite successful in expressing division in fractions whose verbal or symbolic (numeric) expressions were provided through symbolic (numeric) or verbal representations. However, the preservice teachers were found to be very unsuccessful in representing a fraction whose verbal or symbolic 
Table 4. Transition from textual representation to other types of representation.

\begin{tabular}{lccccccccccccccc}
\hline & \multicolumn{3}{c}{ WN/WN } & \multicolumn{3}{c}{ WN/F } & \multicolumn{3}{c}{ F/WN } & \multicolumn{3}{c}{ F/F } & \multicolumn{3}{c}{ Overall } \\
\cline { 2 - 15 } & T & F & NA & T & F & NA & T & F & NA & T & F & NA & T & F & NA \\
\hline Symbol & 100 & 0 & 0 & 94 & 6 & 0 & 100 & 0 & 0 & 100 & 0 & 0 & 98 & 2 & 0 \\
Model & 83 & 17 & 0 & 44 & 39 & 17 & 22 & 33 & 45 & 33 & 50 & 17 & 45 & 35 & 20 \\
Number Line & 61 & 39 & 0 & 50 & 39 & 11 & 28 & 22 & 50 & 50 & 33 & 17 & 47 & 33 & 20 \\
Overall & 81 & 19 & 0 & 63 & 28 & 9 & 50 & 18 & 32 & 61 & 28 & 11 & & & \\
\hline
\end{tabular}

${ }^{*} \mathrm{~T}:$ True, F:False, NA: No answer

Table 5. Transition from symbolic (numerical) representation to other types of representation.

\begin{tabular}{|c|c|c|c|c|c|c|c|c|c|c|c|c|c|c|c|}
\hline & \multicolumn{3}{|c|}{ WN/WN } & \multicolumn{3}{|c|}{ WN/F } & \multicolumn{3}{|c|}{ F/WN } & \multicolumn{3}{|c|}{ F/F } & \multicolumn{3}{|c|}{ Overall } \\
\hline & $\mathbf{T}$ & $\mathbf{F}$ & NA & $\mathbf{T}$ & $\mathbf{F}$ & & $\mathbf{T}$ & $\mathbf{F}$ & NA & $\mathbf{T}$ & $\mathbf{F}$ & NA & $\mathbf{T}$ & $\mathbf{F}$ & NA \\
\hline Verbal & 100 & 0 & 0 & 94 & 0 & 6 & 94 & 0 & 6 & 67 & 0 & 33 & 88 & 0 & 11 \\
\hline Model & 66 & 16 & 17 & 28 & 33 & 39 & 17 & 44 & 39 & 17 & 39 & 44 & 32 & 33 & 34 \\
\hline Number line & 83 & 6 & 11 & 33 & 39 & 28 & 28 & 28 & 44 & 28 & 22 & 50 & 43 & 23 & 33 \\
\hline Overall & 83 & 7 & 9 & 51 & 24 & 24 & 46 & 24 & 29 & 37 & 20 & 42 & & & \\
\hline
\end{tabular}

${ }^{*} \mathrm{~T}:$ True, F:False, NA: No answer

Table 6. Transition from representation via number lines to other types of representation.

\begin{tabular}{|c|c|c|c|c|c|c|c|c|c|c|c|c|c|c|c|}
\hline & \multicolumn{3}{|c|}{ WN/WN } & \multicolumn{3}{|c|}{ WN/F } & \multicolumn{3}{|c|}{ F/WN } & \multicolumn{3}{|c|}{ F/F } & \multicolumn{3}{|c|}{ Overall } \\
\hline & $\mathbf{T}$ & $\mathbf{F}$ & NA & $\mathbf{T}$ & $\mathbf{F}$ & & $\mathbf{T}$ & $\mathbf{F}$ & NA & $\mathrm{T}$ & $\mathbf{F}$ & NA & $\mathbf{T}$ & $\mathbf{F}$ & NA \\
\hline Symbol & 89 & 11 & 0 & 44 & 50 & 5 & 61 & 28 & 11 & 33 & 67 & 0 & 56 & 39 & 4 \\
\hline Verbal & 89 & 11 & 0 & 44 & 45 & 11 & 61 & 28 & 11 & 28 & 61 & 11 & 55 & 36 & 8 \\
\hline Model & 72 & 17 & 6 & 22 & 67 & 11 & 39 & 44 & 17 & 22 & 67 & 11 & 38 & 48 & 11 \\
\hline Overall & 83 & 13 & 2 & 36 & 54 & 9 & 53 & 33 & 13 & 27 & 65 & 7 & & & \\
\hline
\end{tabular}

*T:True, F:False, NA: No answer

Table 7. Transition from representation via models to other types of representation.

\begin{tabular}{|c|c|c|c|c|c|c|c|c|c|c|c|c|c|c|c|}
\hline & \multicolumn{3}{|c|}{ WN/WN } & \multicolumn{3}{|c|}{ WN/F } & \multicolumn{3}{|c|}{ F/WN } & \multicolumn{3}{|c|}{$F / F$} & \multicolumn{3}{|c|}{ Overall } \\
\hline & $\mathrm{T}$ & $\mathrm{F}$ & $\mathrm{NA}$ & $\mathrm{T}$ & $\mathrm{F}$ & $\mathrm{NA}$ & $\mathrm{T}$ & $\mathrm{F}$ & NA & $\mathrm{T}$ & $\mathrm{F}$ & NA & $\mathrm{T}$ & $\mathrm{F}$ & NA \\
\hline Symbol & 89 & 11 & 0 & 38 & 56 & 6 & 72 & 28 & 0 & 17 & 39 & 44 & 54 & 33 & 12 \\
\hline Verbal & 94 & 6 & 0 & 39 & 44 & 17 & 67 & 33 & 0 & 17 & 33 & 50 & 54 & 29 & 12 \\
\hline Number line & 78 & 11 & 11 & 22 & 50 & 28 & 50 & 39 & 11 & 6 & 33 & 61 & 39 & 33 & 27 \\
\hline Overall & 87 & 9 & 3 & 33 & 50 & 17 & 63 & 33 & 3 & 13 & 35 & 51 & & & \\
\hline
\end{tabular}

${ }^{*} \mathrm{~T}:$ True, F:False, NA: No answer

(numeric) expression was provided through models or number lines. Higher success of the pre-service teachers in symbolic representations may be attributed to the fact that traditional teaching methods are used in the learning environments of the pre-service teachers, and algebraic (symbolic) representation is the most suitable type of representation for this method and is featured more in this method. As a matter of fact, Mack (1995) and 
Table 8. Most frequent errors and examples about them.

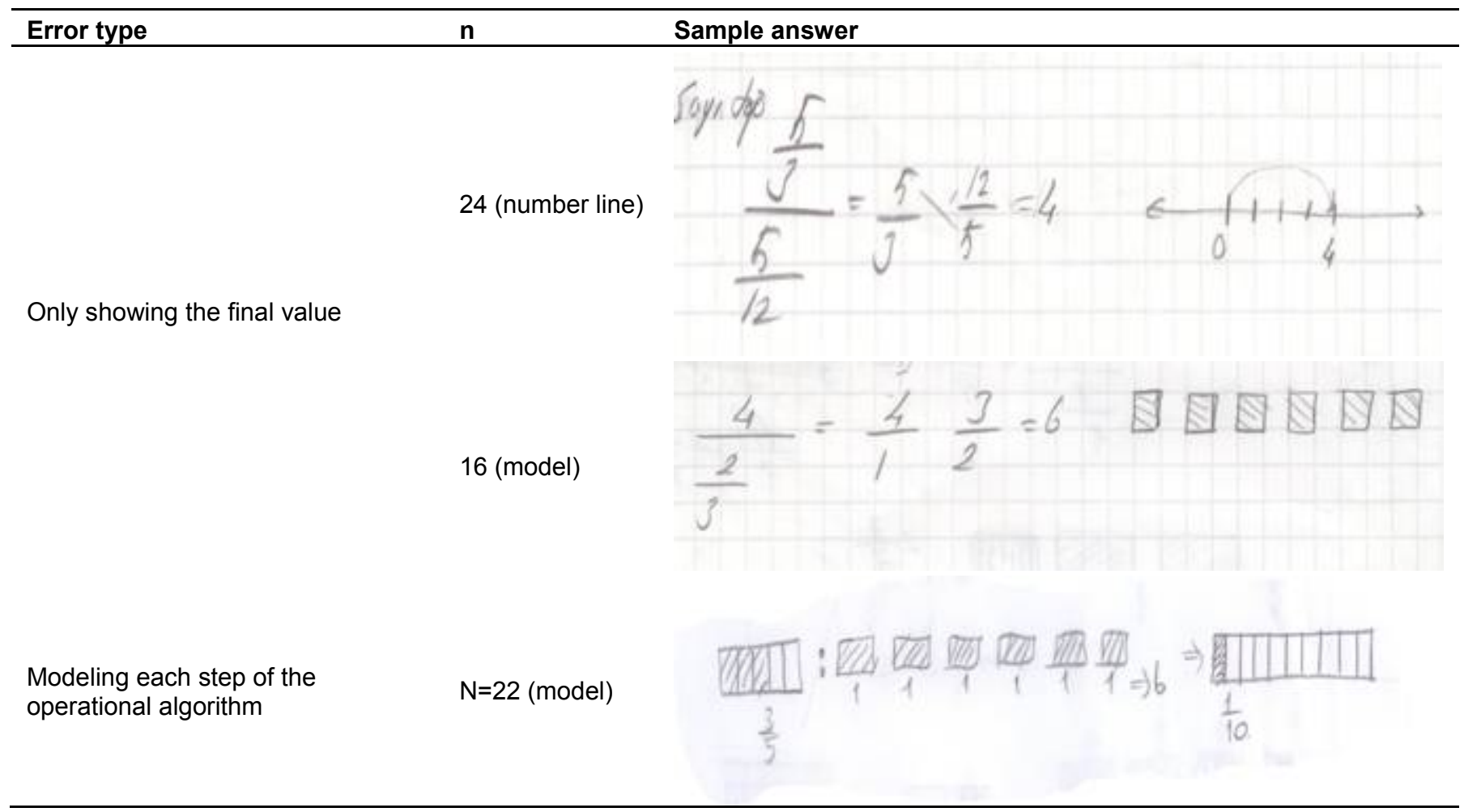

Moseley (2005) obtained findings supporting the abovementioned idea.

The pre-service teachers were able to express a fractional division operation provided through models or represented on a number line by using verbal and numeric (symbolic) representations. This result conflicts with the finding of Billings and Klanderman (2000) that pre-service teachers had difficulty in turning graphical problems into verbal expressions. However, the preservice teachers were found to be very unsuccessful especially in the expressions involving (number:fraction) and (fraction:fraction) while using models or representing via a number line. Thus, it can be said that although the pre-service teachers had good operational skills, they failed to achieve an absolute understanding of the conceptual meaning of division in fractions. Similarly, Toluk (2002) and Durmuş (2005) determined that students were able to perform division in rational numbers algorithmically/operationally, but had difficulty in expressing it conceptually.

The comparison of the performances of the pre-service teachers in transitions between representations reveals that the pre-service teachers were quite successful in expressing a fraction whose verbal or numeric (symbolic) expression was provided through other types of representation, but they were very unsuccessful in representing the fractions that were provided via models or on number lines through other types of representation. This is consistent with the findings of Haser and Ubuz (2002) and Şiap and Duru (2004) that students had difficulty in transiting between the different representations of rational numbers.

On the other hand, the pre-service teachers were more successful in the symbolic representations which they stated that they preferred most in comparison to other representations. However, when they were demonstrating division in fractions via multiple representations, the preservice teachers fell into the error of showing only the result on the model or on the numeric line instead of modeling the operation. Another mistake made by the pre-service teachers while using a model or representing via a number line was showing only the numerical values in the numerator and denominator of the fraction via representations. Based on the mistakes made by the preservice teachers while demonstrating division in fractions through representations, it can be said that the preservice teachers ignored the conceptual dimension of division in general. Researchers (Alacaci, 2009; Olkun 
and Toluk, 2003; Van de Walle, 2004) state that a considerable part of misconceptions in fractions arises from the generalization of habits about natural numbers over fractions.

The pre-service teachers should believe in the contribution of the use of multiple representations in mathematics to education. This is because; teachers can reflect their beliefs and prejudices concerning multiple representations on learning environments, too (Patterson and Norwood, 2004). Different types of representations should be highlighted for conceptual understanding to be achieved on the subject of rational numbers that constitutes a basis for other subjects of mathematics (Kieren, 1976; Vergnaud, 1983). Based on the fact that multiple representations are included in curricula as of the primary education second grade (MEB, 2009), it can be said that teachers have an important responsibility for establishing a strong infrastructure on this subject among students. Therefore, pre-service mathematics teachers, who are the teachers of future, should improve themselves in representing a mathematics subject through different representations in order to introduce conceptual understanding to their students in the future. The importance of the use of multiple representations should be emphasized in the trainings provided to pre-service mathematics teachers during their university education. In addition, trainings regarding the use of multiple representations by pre-service teachers should be increased. The present study was carried out with pre-service mathematics teachers. A similar study may be carried out with teachers and primary education teachers, thereby investigating their skills of using multiple representations.

\section{Conflict of Interests}

The author(s) have not declared any conflict of interests.

\section{REFERENCES}

Aksu M (1997). Student Performance in Dealing with Fraction, J. Educ. Res. 90(6):375-380.

Alacaci C (2009). Öğrencilerin kesirler konusundaki kavram yanılgıları. In E. Bingölbalı ve M.F.

Özmantar (Eds). İlköğretimde karşılaşılan matematiksel zorluklar ve çözüm önerileri, Ankara: PegemA Yayıncılık (pp. 63-94).

Baki A (2006). Kuramdan Uygulamaya Matematik Eğitimi (Mathematics Education from Theory to Practice). Trabzon: Derya Kitabevi.

Başgün M, Ersoy Y (2000). Sayılar ve Aritmetik I: Kesir ve Ondalık Sayıların Öğretilmesinde Bazı Güçlükler ve

Yanılgılar, IV. Fen Bilimleri Eğitimi Kongresi Bildiri Kitabı: s:604-608, MEB Yay., Ankara.

Billings EMH, Klanderman D (2000). Graphical representations of speed: Obstacles preservice K-8 teachers experience. Sch. Sci. Math. 100(8):440-451.

Choike JR (2000). Teaching Strategies for "Algebra for All". Math.
Teacher 93(7):556-561

Çelik D, Baki A (2007). "Öğretmen Adaylarının Cebirde Coklu Gösterimlerden Yararlanma Durumları Üzerine Bir Çalışma. Paper presented at the 7th International Educational Technology Conference, Near East University, North Cyprus.

Davis GE, Hunting RP, Pearn C (1993). What might a fraction mean to a child and how would a teacher know? J. Math. Behav. 12(1):63-76.

Davis RB (1984). Learning Mathematics: The cognitive science approach to mathematics education. Norwood, $\mathrm{NJ}$ : Ablex (as cited in Speiser \& Walter, 2000).

Davis RB, Alston A, Maher CA (1991). Brian's number line representation of fractions. Proceedings of Psychology of Mathematics Education XV. Assisi, Italy.

Driscoll M (1999). Fostering algebraic thinking: A guide for teachers, grades 6-10, Portsmouth, $\mathrm{NH}$ : Heinemann.

Dufour-Janvier B, Bednarz N, Belanger M (1987). Pedagogical considerations concerning the problem of representation. In Claude Janvier (Ed.), Problems of Representation in the Teaching and Learning of Mathematics. Hillsdale, NJ: Erlbaum pp.109-122.

Durmuş S (2005). Rasyonel Sayılarda Bölme İşlemini İlköğretim Öğrencilerin Algılayıșları (Primary School Students' Perception of Division in Rational Numbers). Sakarya Üniversitesi Eğitim Fakültesi Dergisi 9: 97-109.

Even R (1998). Factors Involved in Linking Representations of Functions. J. Math. Behav. 17(1):105-121.

Goerdt LS (2007) The Effect of Emphasizing Multiple Representations on Calculus Students' Understanding of the Derivative Concept. Unpublished EdD, The Universty of Minnesota.

Gürbüz R, Birgin O (2008). Farklı Öğrenim Seviyesindeki Öğrencilerin Rasyonel Sayıların Farklı Gösterim Şekilleriyle İşlem Yapma Performanslarının Karşılaştııılması. Pamukkale Üniversitesi Eğitim Fakültesi Dergisi 23(1):85-94.

Haser Ç, Ubuz B (2002). Kesirlerle Kavramsal ve İşlemsel Beceriler Eğitim ve Bilim, 27(126): 53-61.

Hiebert J, Carpenter $T$ (1992). Learning and teaching with understanding. In: D.A. Grouws (Ed.), Handbook of research on mathematics teaching and learning (pp.65-97). New York: Macmillan.

Hitt F (1998), Difficulties in the Articulation of Different Representations Linked to the Concept of Function. J. Math. Behav. 17(1):123-134.

İpek AS, Işık C, Albayrak M (2005). Sınıf Öğretmeni Adaylarının Kesir İşlemleri Konusundaki Kavramsal Performansları. Kazım Karabekir Eğitim Fakültesi Dergisi 1:537-547.

Kamii C, Clark F (1995). Equivalent Fraction: Their Difficulty and Educational Implication. J. Math. Behav. 14:365-378.

Kaput JJ (1998). Representations, inscripions, descriptions and learning: A kaleidoscope of windows. J. Math. Behav. 17(2):265-281.

Keller BA, Hirsch CR (1998). Student preferences for representations of functions. Int. J. Math. Educ. Sci. Technol. 29(1):1-17.

Kendal M (2002). Teaching and learning introductory differential calculus. Unpublished doctoral dissertation, The University of Melbourne, Australia. Available: http://thesis.lib.unimelb.edu.au/

Kieren TE (1976). On The Mathematical, Cognitive, and Instructional Foundations of Rational Numbers. In: R.A.Lesh (Ed.), Number and Measurement (101-144). Columbus, Oh: Ohio State University, EEIC SMEAC.

Lamon SJ (2001). Presenting and representing: From fractions to rational numbers. In: A.A. Cuoco \& F. R. Curcio (Eds.). The Roles of Representation in School Mathematics: 2001 Yearbook. National Council of Teachers of Mathematics: Reston, VA.

Ma $L$ (1999). Knowing and teaching elementary mathematics: Teachers' understanding of fundamental mathematics in China and the United States. Erlbaum, Mahwah, NJ.

Mack N (1995). Confounding Whole-Number and Fraction Concept When Building on Informal Knowledge. J. Res. Math. Educ. 26(5):422-441.

McGowan M, Tall D (2001). Flexible Thinking, Consistency, and 
Stability of Responses:A Study of Divergence. [Online]: Retrieved on 7-February 2013, at URL http://www.warwick.ac.uk/staff/David.Tall/drafts/dot2001-mcgowentall-draft.pdf.

Minsky M (1975). A framework for representing knowledge. In: P.H. Winston (Ed.), The psychology of computer vision, New York: McGraw-Hill.

http://courses.media.mit.edu/2004spring/mas966/Minsky\%201974\%2 OFramework\%20for\%20knowledge.pdf

Moseley B (2005). Students' Early Mathematical Representation Knowledge: The Effects of Emphasizing Single or Multiple Perspectives of the Rational Number Domain in Problem Solving. Educ. Stud. Math. 60:37-69.

NCTM (2000). Principles and Standards for School Mathematics. Reston,

VA: http://www.nctm.org/uploadedFiles/Math_Standards/12752_exec_pss m.pdf

Olkun S, Toluk Z (2003). İlköğretimde etkinlik temelli matematik öğretimi. Ankara, Anı yayıncılık.

Orhun N (2007). Kesir İşlemlerinde Formal Aritmetik ve Görselleştirme Arasındaki Bilişsel Boşluk. İnönü Üniversitesi Eğitim Fakültesi Dergisi 8(14):99-111.

Patterson N, Norwood K (2004). A case study of teacher beliefs on students' belief about multiple representation. Int. J. Sci. Math. Educ. 2:5-23.

Pesen C (2008). Kesirlerin Sayı Doğrusu Üzerindeki Gösteriminde Öğrencilerin Öğrenme Güçlükleri ve Kavram Yanılgıları. İnönü Üniversitesi Eğitim Fakültesi Dergisi 9(15):157-168.

Piez CM, Voxman MH (1997). Multiple Representations-Using Different Perspectives to Form a Clearer Picture, Mathematics Teachers, 90(2):164-166.

Porzio D (1999). Effects of differing emphases in the use of multiple representations and technology on students' understanding of calculus concepts. Focus On Learning Problems in Mathematics, 21(3):1-29.

Schultz JE, Waters MS (2000). Why Representations?. Math. Teacher 93(6):448.

Speiser R, Walter C (2000). Five women build a number system. Stamford, CT: Ablex Publishing Corporation.

Steffe LP, Cobb P, von Glasersfeld E (1988). Young children's construction of arithmetical meanings and strategies. New York: Springer Verlag.
Steffe LP, von Glasersfeld E, Richards C (1983). Children's counting types: Philosophy, theory and applications. New York: Praeger Scientific.

Stein MK, Baxter JA, Leinhardt G (1990). Subject-Matter Knowledge and Elementary Instruction: A Case from Functions and Graphing. Am. Educ. Res. J. 27(4):639-663.

Şiap I, Duru A (2004). Kesirlerde Geometrik Modelleri Kullanabilme Becerisi. Kastamonu Eğitim Dergisi 12(1):89-96.

Toluk Z (2002). İlkokul Öğrencilerinin Bölme İşlemi ve Rasyonel Sayıları İlişkilendirme Süreçleri. Boğaziçi Üniversitesi Eğitim Dergisi 19(2):81101.

Tzur R (1999). An integrated study of children's construction of improper fractions and the teacher's role in promoting that learning. J. Res. Math. Educ. 30(4):390-416.

Van de Walle JA (2004). Elementary and midddle school mathematics (5th ed.). Virginia Commonwealth University press.

Vergnaud G (1983). Multiplicative Structures. In: R. Lesh and M Landau (Eds). Acquisition of Mathematics Concepts and Processes. (pp.92-126). New York: Academic Press.

Watson JM, Campbell KJ, Collis KF (1993). Multimodal functioning in understanding fractions. J. Math. Behav. 12(1):45-62.

Yang DC, Li MN, Lin Cl (2008). A Study of the Performance of 5th Graders in Number Sense and its Relationship to Achievement in Mathematics. Int. J. Sci. Math. Educ. 6(4):789-807.

\section{Citations}

MEB (2009). İlkoğretim Matematik Dersi 1-5. Sınıflar Öğretim Programı (Primary Education Mathematics Course 1st to 5th Grades Curricula). Ankara.

MEB (2013). İlkoğretim Matematik Dersi 1-5. Sınıflar Öğretim Programı (Primary Education Mathematics Course 1st to 5th Grades Curricula). Ankara. 